\title{
The Effects of Cuminum cyminum L. and Carum carvi L. Seed Extracts on Human Erythrocyte Hemolysis
}

\author{
Omar M. Atrooz ${ }^{1}$ \\ ${ }^{1}$ Department of Biological Sciences, Mutah University, Jordan \\ Correspondence: Omar M. Atrooz, Department of Biological Sciences, P. O. Box (7), Mutah University, Jordan. \\ Tel: 962-797-127-237. E-mail: omihandd@yahoo.com
}

Received: June 10, 2012 Accepted: February 20, 2013 Online Published: March 4, 2013

doi:10.5539/ijb.v5n2p57 URL: http://dx.doi.org/10.5539/ijb.v5n2p57

\begin{abstract}
Cumin (Cuminum cyminum L.) and caraway (Carum carvi L.) are aromatic plants within the Apiaceae family. They have a variety of purposes and demonstrate antioxidant and antimicrobial properties. Methanolic and acetonic seed extracts of both plants were able to neutralize free radicals and carried antioxidant properties. Both seed extracts were able to protect erythrocytes from hemolysis. The methanolic cumin extract showed a higher percentage of protection than both extracts of caraway. Seed extracts of cumin showed slightly higher neutralization ability than caraway seed extracts (57.0 and 52.4\% vs. 44.7 and $39.5 \%$, respectively). Antioxidant properties of both seed plants may be useful in pharmacologic preparations.
\end{abstract}

Keywords: methanolic extract, acetonic extract, DPPH, antioxidant, $\beta$-carotene

\section{Introduction}

Herbs and spices have been used as food for centuries. Spices are important bionutrients both as functional food ingredients and nutritional supplements (Lai \& Roy, 2004). They are used as food additives and play a role in enhancing the taste and flavour aspects of food. In addition, herbs and spices have been used for treating several disorders due to the inherent medicinal properties, particularly ailments of the digestive system (Milan et al., 2008).

Cumin (Cuminum cyminum L.) and caraway (Carum carvi L.) are aromatic plants within the Apiaceae family that are used in foods, fragrances, and medical preparations (liqueurs, mouthwashes, toothpastes, soaps, and perfumes). They are used as antispasmodic, carminative, and appetite stimulating agents (Morton, 1976; Iacobellis et al., 2005).

Cumin is regularly used as a flavoring agent in a number of ethnic cuisines. Cumin seeds have been found to possess significant biological activities, such as antibacterial (Morton, 1976), antifungal, anti-carcinogenic (Gagandeep et al., 2003), anti-diabetic, anti-thrombotic (Dhandapani et al., 2002), and antioxidant properties (Gagandeep et al., 2003; Thippeswamy \& Akhilender, 2005; Ferrie et al., 2011).

In addition, caraway is also used to treat ailments such as flatulence, colic pain, and bronchitis (de Carvalho $\&$ de Fonseca, 2006). The plant caraway plant has been shown to have stomachic, antispasmodic, antibacterial, antifungal, antiulcerogenic, and antiproliferative properties and can be an effective insect repellent (Peirce, 1999; Eddouks et al., 2004; Deeptha et al., 2006). The extract of caraway mainly contains ethereal (essential) oil, aromatic ketone, carvone, D-limonene, fatty oil, protein compounds, waxes, tanning agents, resins, flavonoids, organic acids, coumarin compounds, minerals, and other salts (Dijkstra \& Speckmann, 1980; Weiss, 2002; Dyduch et al., 2006; Agnieszka et al., 2008).

Free radical species are metabolic byproducts of cells that can initiate reactions that damage organic molecules of biological importance and implicated as a factor in a number of health problems, including cancer, heart disease, and possibly the aging process (Gow-Chin et al., 2002; Anagnostopoulou et al., 2006). Antioxidants, either as additives or as pharmaceutical supplements, can terminate free radical reactions in vivo, which can thereby prevent damage to essential cellular molecules, including nucleic acids and proteins (Anagnostopoulou et al., 2006).

The protective effects of plant products are due to several components that have distinct mechanisms of action, including enzymes, proteins, vitamins, carotenoids, flavonoids, anthocyanins, $\beta$-carotene, polyphenols and other 
phytochemicals of the plant (Negi et al., 2003; Argolo et al., 2004; Stasiuk \& Kozubek, 2010). Most antioxidants isolated from higher plants are polyphenols, which have been shown to have antibacterial, anticarcinogenic, anti-inflammatory, antiviral, antiallergic, estrogenic, and immune-stimulating biological properties (Stasiuk \& Kozubek, 2008, 2010). The antioxidant activity of phenolics is mainly due to their redox properties, which allow them to act as reducing agents, hydrogen donors, singlet oxygen quenchers, and metal chelators (Ali et al., 2005).

The aim of this study was to evaluate the antioxidant activity of the methanolic and acetonic extracts of Cuminum cyminum L. and Carum carvi L. seeds and to demonstrate their effects on the permeability of the human erythrocyte membrane.

\section{Materials and Methods}

\subsection{Chemicals}

Methanol (Scharlau, Barcelona, Spain); Gallic acid, $\beta$-carotene, and 1, 1-Diphenyl-2-picryl-hydrazyl (DPPH) were purchased from Sigma-Aldrich, Germany. The $\mathrm{FeSO}_{4}: 7 \mathrm{H}_{2} \mathrm{O}$ reagent was purchased from Fluka/Purum, $\mathrm{Ph}$. Eur. Switzerland.

\subsection{Plant Materials}

Plant seed samples of Cuminum cyminum L. and Carum carvi L. seeds were purchased from local markets. One hundred grams of each seed was crushed and ground in a household grinder.

\subsection{Preparation of the Extracts of Cumin and Caraway}

The powder of each plant seed was soaked with methanol or acetone solvents and extracted by continuous shaking for $7 \mathrm{~h}$ at room temperature (RT). The extracts were filtered and the residues were soaked again with the same solvent for an additional $4 \mathrm{~h}$ at RT. The extracts were then filtered, combined, dried using a rotary evaporator (RV 05-ST Janke and Kunkel, IKA, Germany), and weighed. The obtained residue was re-dissolved in methanol or acetone for further analyses.

\subsection{Free Radical-Scavenging Activity}

The effects of the extracts on DPPH radicals were estimated according to the procedure described by Moure et al. (2000) with slight modification. Two milliliters of a $3.6 \times 10^{-5} \mathrm{M}$ methanolic solution of DPPH were added to 50 $\mu \mathrm{l}$ of $100 \mu \mathrm{M}$ sample extract. The decrease in absorbance at $515 \mathrm{~nm}$ was monitored with a Vis-Spectrophotometer (Biotech Engineering Management Co. Ltd, UK) at different time intervals. Gallic acid was used as a positive control. The scavenging effect (absorbance) was plotted against the time and the percentage of DPPH radical scavenging ability (IP) of the sample was calculated from the absorbance value at the end of $180 \mathrm{~s}$ and $60 \mathrm{~min}$ duration as follows:

$$
\mathrm{IP}=\left(\text { absorbance }_{\mathrm{t}}=0 \mathrm{~min}-\text { absorbance }_{\mathrm{t}}=180 \mathrm{~s} \text { or } 60 \mathrm{~min}\right) \mathrm{x} 100 / \text { absorbance }_{\mathrm{t}}=0 \mathrm{~min}
$$

\section{$2.5 \beta$-Carotene Bleaching Assay}

The $\beta$-carotene bleaching assay was carried out according to the procedure previously described (Wettasinghe $\&$ Shahidi, 1999; Amin et al., 2006) with slight modifications. Briefly, $2 \mathrm{ml}$ of $\beta$-carotene solution $(0.2 \mathrm{mg} / \mathrm{ml}$ chloroform) were pipetted into a round-bottom flask containing $20 \mu 1$ linoleic acid and $200 \mu 1$ Tween 20 . The mixture was then evaporated at $40^{\circ} \mathrm{C}$ for $10 \mathrm{~min}$ using a rotary evaporator to remove chloroform. After evaporation, the mixture was immediately added to $100 \mathrm{ml}$ of distilled water. The mixture was vigorously agitated to form an emulsion. Five milliliter aliquots of the emulsion were transferred into different test tubes containing $200 \mu \mathrm{l}$ of extract. The mixture was then gently mixed and placed in a water bath at $50^{\circ} \mathrm{C}$ for $2 \mathrm{~h}$. The sample was incubated for $15 \mathrm{~min}$ and the absorbance was measured at $470 \mathrm{~nm}$. A blank solution was prepared containing the same concentration of sample without $\beta$-carotene. All measurements were performed in triplicate.

\subsection{Preparation of RBCs}

Human Blood samples were collected into heparinized tubes and the RBCs were separated from plasma by centrifugation at $3000 \mathrm{rpm}$ for $20 \mathrm{~min}$ at room temperature. The crude RBCs were washed with the same volume of phosphate-buffered saline (PBS) pH 7.4 followed by centrifugation twice. The packed RBCs were then suspended in four volumes of PBS solution.

\subsection{Assay for Free Radical-Mediated Hemolysis}

The method described by Miki et al. (1987) was used with slight modification. Two milliliters of RBC suspension in PBS (15\%) was added to the same volume of $0.001 \mathrm{M} \mathrm{FeSO}_{4}$ in PBS solution containing $100 \mu \mathrm{l}$ of 
seed extract. The reaction mixture was shaken gently in a rotary shaker for $150 \mathrm{~min}$ at $37^{\circ} \mathrm{C}$. After incubation, 8 $\mathrm{ml}$ of PBS solution was added into the reaction mixture.

The diluted reaction mixture was then centrifuged at $3000 \mathrm{rpm}$ for $10 \mathrm{~min}$. The absorbance (A) of the supernatant at $450 \mathrm{~nm}$ was recorded with a Vis-Spectrophotometer. The percent inhibition was calculated by the following equation: $\%$ Inhibition $=\left(1-\mathrm{A}_{\text {antioxidant }} / \mathrm{A}_{\mathrm{FeSO}}\right) \times \mathrm{X} 100$, where $\mathrm{A}_{\mathrm{FeSO} 4}$ is the absorbance of the sample containing no extract and $\mathrm{A}_{\text {antioxidant }}$ is the absorbance of the sample containing extract.

\subsection{Statistical Analysis}

Data represent the mean of three replicate samples for each plant seed extract \pm standard deviation (SD). A P < 0.05 was considered statistically significant.

\section{Results and Discussion}

Two complementary assays were used to assess the antioxidant activity of cumin and caraway seed extracts: the DPPH free radical scavenging assay and the $\beta$-carotene bleaching assay. Both cumin and caraway seed extracts were able to neutralize free radicals over a period of $60 \mathrm{~min}$ in the DPPH assay, with most of the neutralization occurring quickly within the first $30 \mathrm{~s}$. The steady state was reached within $10 \mathrm{~min}$, and it appeared that the acetonic extracts of both seeds had less antioxidant activity than the methalonic extracts. The methanolic and acetonic extracts of cumin showed slightly higher neutralization ability than the respective extracts from caraway within three minutes of assay initiation (57.0 and $52.4 \%$ for cumin and 44.7 and $39.5 \%$ for caraway (Figure 1A). Importantly, the neutralization level stayed relatively the same over 60 min (Figure 1B).
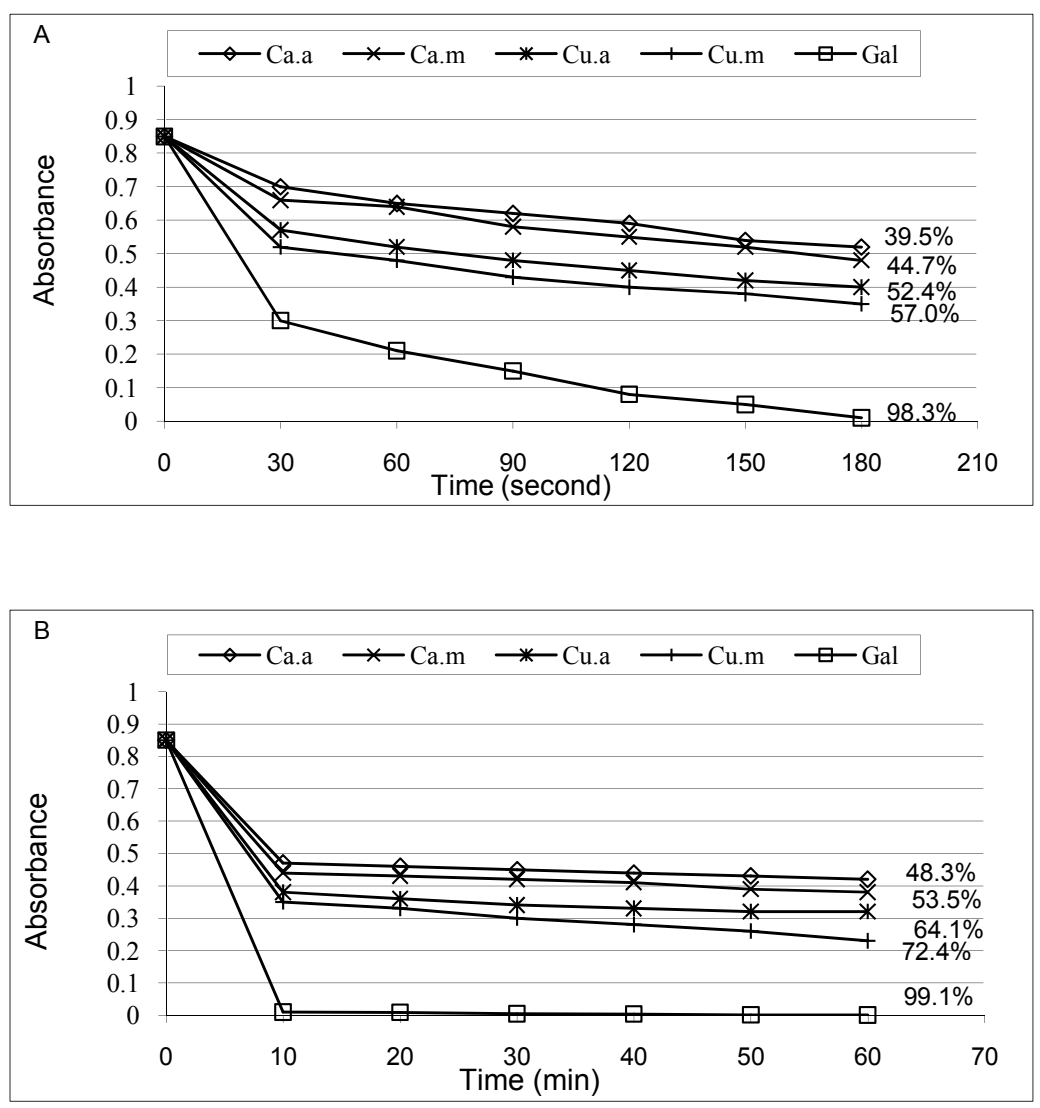

Figure 1. Kinetic behavior of methanolic and acetonic extracts $(100 \mu \mathrm{M})$ of cumin and caraway seeds by reaction with methanolic solution of DPPH spectrophotometrically at $515 \mathrm{~nm}$ as a function of time at $3 \mathrm{~min}$ (A) and 60 min (B). Methanolic extract of cumin (Cu.m), acetonic extract of cumin (Cu.a), methanolic extract of caraway (Ca.m), acetonic extract of caraway (Ca.a). Gallic acid was used as a positive control (Gal). Values at the end of the kinetic curves represent the percentage of radical-scavenging of DPPH 
The antioxidant ability of both seed extracts in a $\beta$-carotene assay was shown in Table 1 , both methanolic and acetonic extracts of cumin and caraway seeds inhibited the oxidation of $\beta$-carotene in a dose-dependent manner. These results were in agreement with the DPPH assay results, indicating that both cumin and caraway seed extracts have antioxidant activity. In addition, the observations correlated with the nature and concentration of the antioxidant molecules in the samples.

Table 1 . Radical scavenging activity (\%) of methanolic and acetonic extracts of cumin and caraway by $\beta$-carotenelinoleate model system

\begin{tabular}{|c|c|c|c|c|}
\hline & \multicolumn{4}{|c|}{ Radical scavenging activity (\%) } \\
\hline $\begin{array}{c}\text { Extract } \\
\text { concentration } \\
(\mu \mathrm{M})\end{array}$ & $\begin{array}{c}\text { Methanolic } \\
\text { cumin } \\
\text { extract }\end{array}$ & $\begin{array}{l}\text { Acetonic } \\
\text { cumin } \\
\text { extract }\end{array}$ & $\begin{array}{c}\text { Methanolic } \\
\text { caraway } \\
\text { extract }\end{array}$ & $\begin{array}{c}\text { Acetonic } \\
\text { caraway } \\
\text { extract }\end{array}$ \\
\hline 10 & $32 \pm 1.3$ & $25 \pm 2.1$ & $18 \pm 2.7$ & $13 \pm 1.8$ \\
\hline 50 & $47 \pm 2.0$ & $39 \pm 1.8$ & $31 \pm 2.2$ & $28.5 \pm 2.6$ \\
\hline 100 & $68 \pm 3.1$ & $58 \pm 2.6$ & $51.2 \pm 2.1$ & $49.3 \pm 2.2$ \\
\hline
\end{tabular}

Data are shown as means $\pm \mathrm{SD}(\mathrm{n}=3)$.

The above findings showed the antioxidant activities of cumin and caraway seed extracts in in vitro systems. In order to explore the antioxidant properties of the extracts in a cell based system, the extracts were incubated with isolated human erythrocytes from healthy adult volunteers. Inhibition of human erythrocyte hemolysis was differently inhibited by cumin and caraway seed extracts in a dose-dependent manner, and exhibited approximately $38 \%$ and $54.6 \%$ cell lysis in the presence of $100 \mu \mathrm{M}$ of the methanolic extracts ( respectively) compared to control cells (Figures 2 and 3). In general, the methanolic extract of cumin showed greater effects in prevention of cell lysis compared to the acetonic extract. In contrast, human erythrocyte hemolysis exhibited markedly less inhibitory effects to methanolic and acetonic extracts of Caraway seed, with the highest percentage of cell lyses occurring with $100 \mu \mathrm{M}$ of acetonic Caraway seed extract (Figure 3). Taken together, these data show that the lysis of human erythrocytes has been inhibited by the extracts of cumin and caraway seeds ( $62 \%$ and $45.4 \%$, respectively), with the highest effect of inhibition for cumin seed extracts.

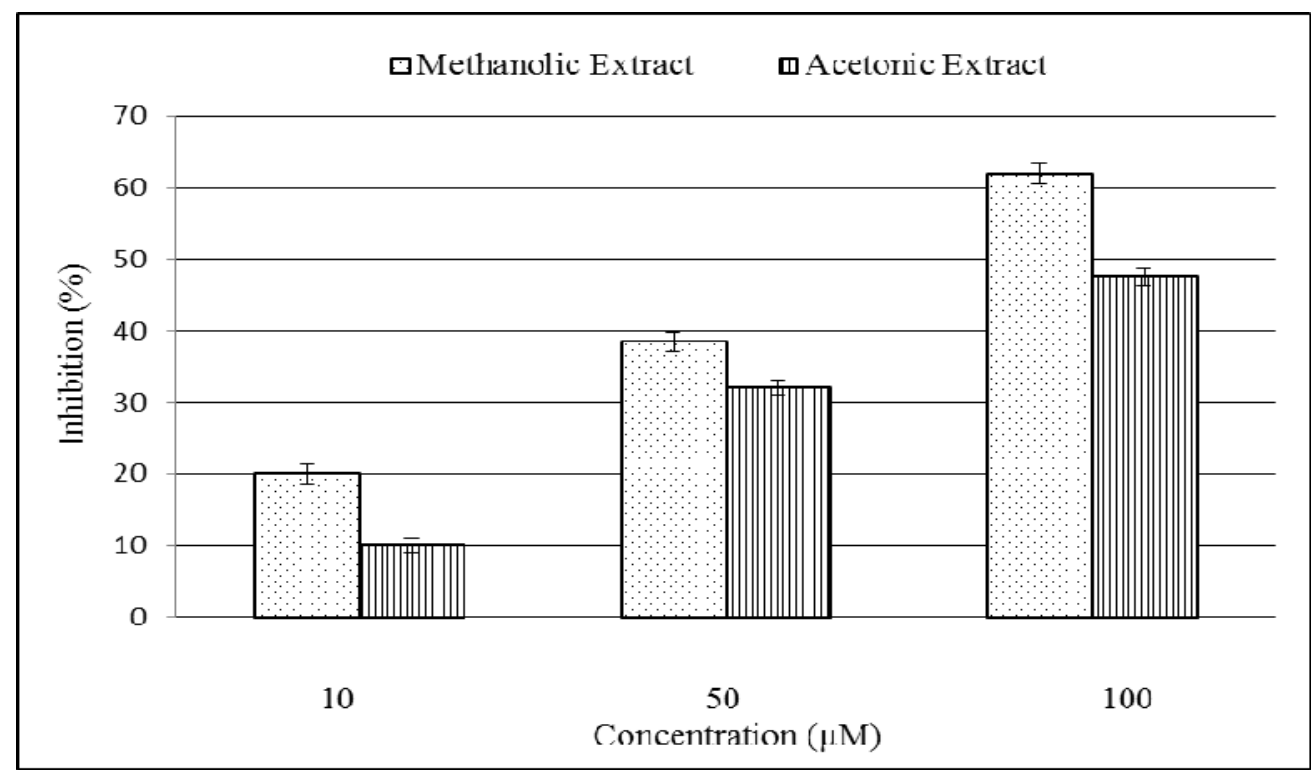

Figure 2. Inhibition Percentage (\%) of human erythrocytes hemolysis by different concentrations $(10 \mu \mathrm{M}, 50 \mu \mathrm{M}$, $100 \mu \mathrm{M})$ of methanolic and acetonic extracts of cumin. Data are shown as means $\pm \mathrm{SD}$ 


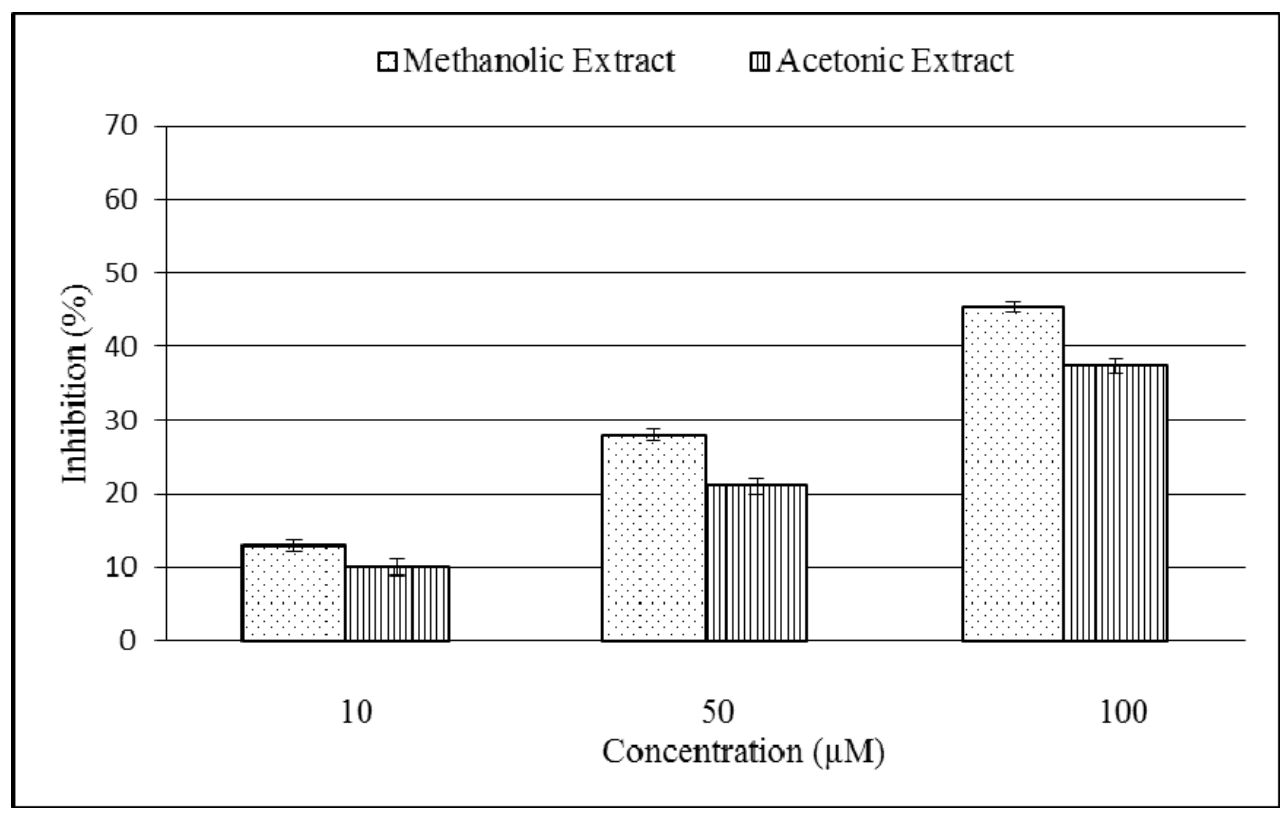

Figure 3. Inhibition Percentage (\%) of human erythrocytes hemolysis by different concentrations $(10 \mu \mathrm{M}, 50 \mu \mathrm{M}$, $100 \mu \mathrm{M})$ of methanolic and acetonic extracts of caraway. Data are shown in means $\pm \mathrm{SD}$

These results indicated that seed extracts of cumin and caraway may protect human erythrocytes against hemolysis may be due to the presence of bioactive compounds that perform a radical-scavenging activity. The antioxidant effectiveness of the bioactive molecules in the extract depends on the type and concentrations of these molecules, location of hydroxyl groups, hydrophobicity/hydrophilicity; their interaction with phospholipids, hemoglobulin, iron and other compounds in erythrocytes that determines the antioxidant power of the extract.

Free radicals are generated through metabolic processes in human erythrocytes as well as other cell types, which can cause hemolysis. Therefore, we next assessed whether extracts from cumin and caraway seeds could prevent free radical-mediated membrane lysis of RBCs. A hemolysis assay was performed in the presence or absence of acetonic and methanolic extracts of cumin and caraway seeds alone or in combination with (antioxidants) Gallic acid, ascorbic acid, and pyrogallol. As shown in Table 2, the methanolic and acetonic extracts of cumin and caraway inhibited hemolysis of human erythrocytes by $62 \pm 3.4,47 \pm 4.2,45.4 \pm 1.3$, and $37.3 \pm 1.2 \%$, respectively, compared to control. The addition of Gallic acid, ascorbic acid, or pyrogallol to the seed extracts demonstrated an additive effect in inhibiting hemolysis to varying levels (Table 2). These results indicated that the methanolic and acetonic extracts of cumin and caraway seeds can protect erythrocytes from hemolysis. Cumin seed extracts showed a slightly higher protective capacity compared to caraway.

This study showed that both seed extracts have antioxidant properties, as shown by the DPPH and $\beta$-carotene assays. In addition, these seed extracts can inhibit free-radical-mediated hemolysis of RBCs. To the best of our knowledge, this is the first study to specifically explore the antioxidant properties of two seed extracts of cumin and caraway.

In conclusion, the results demonstrated that future studies are needed to explore the in vivo effects of these extracts as well as their potential use as antioxidants for human use. Also, the results suggested that these seed extracts may have effectiveness as antioxidants in food supplements and pharmacological preparations or may be able to be used in liposomal technologies for improved delivery. 
Table 2. Inhibition percentage (\%) of methanolic and acetonic extracts $(100 \mu \mathrm{M})$ of cumin and caraway on the hemolysis of human erythrocytes

\begin{tabular}{ll}
\hline Sample & Inhibition (\%) \\
\hline Methanolic cumin extract & $62 \pm 3.4$ \\
Methanolic cumin extract + Gallic acid & $84.8 \pm 2.8$ \\
Methanolic cumin extract + vitamin C & $72 \pm 3.3$ \\
Methanolic cumin extract + pyrogallol & $88.6 \pm 1.3$ \\
Acetonic cumin extract & $47 \pm 4.2$ \\
Acetonic cumin extract + Gallic acid & $78.4 \pm 2.1$ \\
Acetonic cumin extract + vitamin C & $68.6 \pm 3.5$ \\
Acetonic cumin extract + pyrogallol & $81.2 \pm 2.4$ \\
Methanolic caraway extract & $45.4 \pm 1.3$ \\
Methanolic caraway extract + Gallic acid & $72 \pm 5.1$ \\
Methanolic caraway extract + vitamin C & $68 \pm 3.5$ \\
Methanolic caraway extract + pyrogallol & $85 \pm 4.6$ \\
Acetonic caraway extract & $37.3 \pm 1.2$ \\
Acetonic caraway extract + Gallic acid & $59 \pm 4.4$ \\
Acetonic caraway extract + vitamin C & $54 \pm 3.0$ \\
Acetonic caraway extract + pyrogallol & $73 \pm 5.0$ \\
Pyrogallol & $92 \pm 4.3$ \\
Vitamin C & $78 \pm 3.6$ \\
Gallic acid & $95 \pm 5.2$ \\
\hline
\end{tabular}

Data are shown as means \pm standard deviation $(\mathrm{n}=3)$.

\section{References}

Agnieszka, N., Jan, D. Y., \& Norbert, B. (2008). Flavonoid content and antioxidant activity of Caraway roots (Carum carvi L.). Vegetable Crops Research Bulletin, 68, 127-133.

Ali, A. A., Abdelhak, M., George, B., \& Panagoitis, k. (2005). Tea and herbal infusions: Their antioxidant activity and phenolic profile. Food Chemistry, 89, 27-36. http://dx.doi.org/10.1016/j.foodchem.2004.01.075

Amin, I., Norazaidah, Y., \& Emmy Hainida, K. I. (2006). Antioxidant activity and phenolic content of raw and $\begin{array}{lllll}\text { blanched Amaranthus } & \text { Foecies. }\end{array}$ http://dx.doi.org/10.1016/j.foodchem.2004.10.048

Anagnostopoulou, M. A., Kefalas P., Papageorgiou, V. P., Assimopoulou, A. N., \& Boskou, D. (2006). Radical scavenging activity of various extracts and fractions of sweet orange peel (Citrus sinensis). Food Chemistry, 94, 19-25. http://dx.doi.org/10.1016/j.foodchem.2004.09.047

Argolo, A., Sant'Ana, A., Pletsch, M., \& Coelho, L. (2004). Antioxidant activity of leef extracts from Bauhinia monandra. Bioresource Technology, 95, 229-233. http://dx.doi.org/10.1016/j.biortech.2003.12.014

de Carvalho C., \& da Fonseca M. (2006). Carvone: Why and how should one bother to produce this terpene. Food Chem., 95, 413-422. http://dx.doi.org/10.1016/j.foodchem.2005.01.003

Deeptha, K., Kamaleeswari, M., Sengottuvelan, M., \& Nalini, N. (2006). Dose dependent inhibitory effect of dietary caraway on 1,2-dimethylhydrazine induced colonic aberrant crypt foci and bacterial enzyme activity in rats. Invest New Drugs, 24, 479-488. http://dx.doi.org/10.1007/s10637-006-6801-0

Dhandapani, S., Subramanian, V., Rajagopal, S., \& Namasivayam, N. (2002). Hypolipidemic effect of Cuminum cyminum L. on Alloxan-induced diabetic Rats. Pharmacological Research, 46, 251-255. http://dx.doi.org/10.1016/S1043-6618(02)00131-7 
Dijkstra, H., \& Speckmann, G. (1980). Autotetraploidy in caraway (Carum carvi L.) for the increase of the aetheric oil content of the seed. Euphytica, 29, 89-96. http://dx.doi.org/10.1007/BF00037252

Dyduch, J., Najda A., \& Brzozowski N. (2006). Growth and chemical content of caraway(Carum carvi L.) in the first year of cultivation. Folia Hortic. Sup., 1, 108-112.

Eddouks M., Lemhadri A., \& Michel J. (2004). Caraway and caper: Potential anti-hyperglycaemic plants in diabetic rats. J. Ethnopharmacol., 94,143-148. http://dx.doi.org/10.1016/j.jep.2004.05.006

Ferrie, M., Bethune T., Arganosa G., \& Waterer D. (2011). Field evaluation of doubled haploid plants in the Apiaceae: dill (Anethum graveolens L.), caraway (Carum carvi L.), and fennel (Foeniculum vulgare Mill.). Plant Cell Tiss Organ Cult., 104, 407-413. http://dx.doi.org/10.1007/s11240-010-9821-6

Gagandeep, S., Dhanalakshi, E., Mendiz, A., Rao, R., \& Kale, R. (2003). Chemopreventive effects of Cuminum cyminum L. in chemically induced forestomach and uterine cervix tumors in marine model system. Nutrition and Cancer, 7, 171-180. http://dx.doi.org/10.1207/s15327914nc4702_10

Gow-Chin Y., Pin-Der D., \& Hui-Ling T. (2002). Antioxidant and pro-oxidant properties of ascorbic acid and Gallic Acid. Food Chemistry, 79, 307-313. http://dx.doi.org/10.1016/S0308-8146(02)00145-0

Iacobellis, N., Cantore P., Capasso, F., \& Senatores, F. (2005). Antibacterial Activity of Cuminum cyminum L. and Carum carvi L. Essential Oils. J. Agric. Food Chem., 53, 57-61. http://dx.doi.org/10.1021/jf0487351

Lai, P., \& Roy, J. (2004). Antimicrobial and chemopreventive properties of herbs and spices. Current Medicinal Chemistry, 11, 1451-146. http://dx.doi.org/10.2174/0929867043365107

Miki, M., Tamai, M., Yamamoto, Y., \& Niki, E. (1987). Free radical chain oxidation of rat red blood cells by molecular oxygen and its inhibition by $\alpha$-tocopherol. Arch. Biochem. Biophys, 258, 373-380. http://dx.doi.org/10.1016/0003-9861(87)90358-4

Milan, K., Hemang, D., Purnima, K., \& Prakash V. (2008). Enhancement of digestive enzymatic activity by cumin (Cuminum cyminum L.) and role of spent cumin as a bionutrient. Food Chemistry, 110, 678-683. http://dx.doi.org/10.1016/j.foodchem.2008.02.062

Morton, J. F. (1976). Herbs and Spices. New York: Golden Press.

Moure, A., Franco, D., Sineiro, J., Dominguez, H., Hunez, M., \& Lema, J. (2000). Evaluation of extracts from Gevuina avellana hulls as antioxidants. Journal of Agricultural and Food Chemistry, 48, 3890-3897. http://dx.doi.org/10.1021/jf000048w

Negi, P., Jayaprakasha, G., \& Jena, B. (2003). Antioxidant and antimutagenic activities of pomegranate peel extracts. Food Chemistry, 80, 393-397. http://dx.doi.org/10.1016/S0308-8146(02)00279-0

Peirce A. (1999). The American pharmaceutical association practical guide to natural medicines. New York: Stonesong Press.

Stasiuk, M., \& Kozubek A. (2008). Membrane perturbing properties of natural phenolic and resorcinolic lipids. FEBS Letters, 582, 3607-3613.

Stasiuk, M., \& Kozubek, A. (2010). Biological activity of phenolic lipids. Cell. Mol. Life Sci., 67, 841-860. http://dx.doi.org/10.1007/s00018-009-0193-1

Thippeswamy, N., \& Akhilender K. (2005). Antioxidant potency of cumin varieties-cumin, black cumin and bitter cumin on antioxidant systems. Eur. Food Res. Technol., 220, 472-476. http://dx.doi.org/10.1007/s00217-004-1087-y

Weiss, E. (2002). Spice Crops. Australia: CABI Publishing.

Wettasinghe, M., \& Shahidi, F. (1999). Antioxidant and free radicals scavenging properties of ethanolic extracts of defatted borage (Borago officinalis L.) seeds. Food Chemistry, 67, 399-414. http://dx.doi.org/10.1016/S0308-8146(99)00137-5 